Vol. 15 (2006): 375-387.

\title{
Assessing the recreational demand for agricultural land in Finland
}

\author{
Eija Pouta \\ MTT Agrifood Research Finland, Economic Research, Luutnantintie 13, FI-00410 Helsinki, Finland, \\ e-mail: eija.pouta@mtt.fi \\ Ville Ovaskainen \\ Finnish Forest Research Institute, Unioninkatu 40 A, FI-00170 Helsinki, Finland
}

\begin{abstract}
It is widely assumed that the scenic attractiveness and other public good aspects of agricultural land can be utilized as a source of livelihood in rural areas in the form of recreation and tourism. In this study we use two approaches to consider whether agricultural landscapes are preferred as a destination for recreation (day trips) and rural tourism (overnight trips). We first analyse the choice of recreation site type based on a model that aggregates sites using the presence of agricultural land as an aggregation variable. Population survey data on recreation trips reveal an association between the respondent's living environment, recreational activities and visit characteristics and the probability of choosing a destination with agricultural land. Second, we also estimate the demand functions for trips to agricultural sites and other destination types to consider whether the presence of agricultural land, as opposed to other land use categories, increases the number of trips and the benefits of recreation. The results suggest that agricultural landscapes are inferior to alternative site types in terms of per-trip benefits. However, agricultural landscapes are associated with high annual benefits because of the high rate of visitation.
\end{abstract}

Key-words: recreation, rural tourism, participation, demand, travel cost method

\section{Introduction}

Rural areas have importance in providing people with public goods in the form of open spaces, sceneries, nature and relaxation. The supply of these public goods is likely to decrease as traditional farming disappears in some areas and inten- sifies in others (e.g., Bonnieux et al. 1998, LeGoffe 2000). At the same time, it seems that the demand for these public good aspects of rural areas has increased, although the value of the goods to the general public is still largely unknown (Randall 2000, Hall et al. 2004). The importance of the public good characteristics of private agricultural areas has recently been emphasised, particularly in the 
framework of multifunctional agriculture (OECD 2001, Dobbs and Pretty 2004). As the current level of public subsidies to agriculture has been challenged, their justification has partly been found in multifunctionality (Peterson 2002). The multiple functions of agriculture consist of non-market goods produced concurrently with food and fibre. The functions of agriculture most commonly included in the discussion are food security, environmental benefits and rural employment (OECD 2001). In this study we are particularly interested in agriculture as the producer of an environment that is suitable for recreation and tourism.

The environmental goods of agricultural land are public amenities that include use and non-use benefits. Use benefits are considered to consist of scenic views and wildlife habitats, opportunities for outdoor recreation and protection against the external costs of urbanization (e.g., Ready et al. 1997). Non-use benefits are considered to include the knowledge that agriculture, which is considered an important part of the character and heritage of rural areas, will survive. Economic valuation studies (for a review of methods, see Vanslembrouck and Van Huylenbroeck 2005) have shown the value of some non-market components of agricultural environments (for a review of results, see Hall et al. 2004). However, it has not been possible to draw any general quantitative conclusions about the importance of various benefits. Nevertheless, the value of agricultural landscapes has been found to be positive and even considerable in non-market valuation studies (Dillman and Bergstrom 1991, Ready et al. 1997, Hackl and Pruckner 1997, Rosenberger and Walsh 1997). The non-market value of agricultural landscapes has also been found to be high in comparison to the returns from traditional farming (Fleischer and Tsur 2000) or reforestation of the target area (Raffaelli et al. 2004).

The public good properties of agricultural land are expected to provide an opportunity for new sources of livelihood in rural areas, as the relative share of rural tourism is growing (Van Huylenbroeck et al. 2006). The development of tourism has been regarded as a promising diversification scheme for rural regions in strategies for rural tour- ism that have been implemented in virtually all industrialised countries (e.g. Slee et al. 1997, Garrod and Whitby 2005). The promotion of smallscale tourism in rural areas can also generate considerable economic effects (Fleischer and Felsenstein 2000). Nevertheless, despite various rural development policy measures and initiatives, research into the demand for and supply of rural tourism services has been quite limited within agricultural economics (Skuras et al. 2006).

In Finland, as in other countries, policy makers see the development of tourism as a means of promoting economic growth and eliminating unemployment in rural areas (Ympäristöministeriö 2002). Seven percent of Finland's land area is agricultural land (Agricultural Statistics in Finland 2005). Almost all the agricultural land consists of cultivated fields, while $9 \%$ is in the form of setaside fields and $1 \%$ comprises valuable traditional agricultural biotopes such as meadows (Finnish Environment Administration 2005). In Finland, recreational use of the natural environment is based on the traditional common right of access to both private and public land. However, the recreational use of fields is somewhat restricted. During the growing season, walking on fields is permitted on field tracks or by ditches, while cross-country skiing on fields is permitted in winter. Despite these restrictions, agricultural land provides opportunities for certain recreation activities. Although the landscape and environmental functions of agriculture in Finland have been found less important in public opinion than the functions associated with food safety, food security and rural viability (Yrjölä and Kola 2004), some studies have cited a strong preference for agricultural sceneries when compared to afforestation (Karjalainen and Komulainen 1998, Tyrväinen and Tahvanainen 2000). Some scenic preference studies have focused on the management regimes of agricultural land, finding buffer strips along main ditches and rivers to have a positive effect on the scenic beauty (Tahvanainen et al. 2002).

The results of preference studies lead us to expect that agriculture and the agricultural environment can support the development of recreation and rural tourism. Despite the scenic importance 
Vol. 15 (2006): 375-387.

of cultivated agricultural land and the expected importance of tourism and recreation in rural areas, there have been only a few published analyses of the actual use and suitability of agricultural land for tourism and recreation. The recreational use of rural land may not require active agriculture (Hall et al. 2004), but agriculture nevertheless has an effect on the prerequisites for recreational use. Using a stated preference application, Goossen and Langers (2000) assessed perceptions of the suitability of rural areas for various types of typical recreational activity. The land-use patterns for pure agricultural land were found to reduce the quality of the area for walking and cycling. In contrast, mixed areas of forest, agriculture, sand, moor and dunes were perceived as more preferable for these activities. Wytrzens and Mayer (1999) found that farmers consider grasslands to have aesthetic value as well as importance for recreational use, particularly in hunting and shooting. The most important qualities of the agricultural landscape that support recreation are the availability of open scenery and visibility, variation in vegetation with colourful cultivated flowering plants (Arriaza et al. 2004), and special biotopes for birds and other animals. Some characteristics of the land type may also mitigate against recreation. Exposure to wind and sunshine may sometimes be limiting factors, as well as restrictions to access because of growing crops.

In valuation studies, an agricultural landscape has been found to increase the non-market benefits of recreation in the Mediterranean setting (Fleischer and Tsur 2000). Some characteristics of agricultural land, such as the presence of grasslands (Le Goffe and Delache 1997, Vanslembrouck et al. 2005), have been found to increase the potential for rural tourism, while others, such as glasshouses and a nitrogen surplus, have been found to diminish the value in tourism (Vanslembrouck et al. 2005). There has also been an indication that a working farm does not have value for visitors but helps to efficiently produce tourism products such as accommodation. (Fleischer and Tchetchik 2005).

In the following analysis we focus on the contribution of agricultural land to recreation and tourism. Rather than stated preference data, we use data on the actual choices people make when they select a destination. We focus on those conditions under which an individual chooses an agricultural environment for recreation. We first define the characteristics of the living environment of visitors and the visit characteristics that increase the probability of choosing agricultural land as a destination for day trips and overnight trips. Secondly, we estimate the demand functions for trips and analyze whether agricultural land, as opposed to other land use categories, is an attraction that increases the number of trips and the benefits of recreation.

In the following section we define the demand models used in the study. The data section reports the way in which the data from the national outdoor recreation demand and supply inventory (Pouta and Sievänen 2001) are used. The results first describe the choice of destination site type for day trips and overnight trips, and secondly the demand for and benefits of day trips and overnight trips. In the discussion section the implications for the management of agricultural areas and for agricultural policy are appraised.

\section{Recreation demand models}

Models of recreation demand, particularly models of site choice, can be used to examine the characteristics of agricultural land as a destination site (e.g., Parsons and Kealy 1992, Englin et al. 1996). When the use of agricultural lands is examined, the demand is not directed to a certain area but to a certain area type (see Fleischer and Tsur 2003). In this study our first approach is to model visitors' choices, conscious or unconscious, between agricultural land and some other type of environment, such as forest land. In our case, the typical site choice model is not applicable because under common right of access it is difficult to define confined sites and the set of choice options. When the selection of site type is modelled, the attributes of a given area and of the possible substitute areas cannot be used as explanatory variables. Instead, ex- 
Pouta, E. \& Ovaskainen, V. Assessing the recreational demand for agricultural land in Finland

planatory variables relate to the personal characteristics of the choice maker, to his or her living environment, and to the characteristics of the visit or trip. For day visits it can be assumed that the supply of agricultural land in the living environment increases the probability of using it, and that the supply of alternatives may decrease the probability of use. An individual who prefers agricultural land over some other type of environment will be willing to accept a greater expense in order to use agricultural land rather than some other type of land. If the supply of agricultural areas is high in comparison to other site types, the expenses of using these areas would also be low, even if they were preferred as a recreation environment. However, if this effect of supply is captured, the genuine preferences for recreation site types can be revealed.

In the analysis, the use of agricultural land is described with a dichotomous variable that receives a value of 1 if the respondent's latest trip was taken to an area with agricultural land and a value of 0 for other types of area. Destination type choice depends on the characteristics of the living environment (e.g., supply of areas available for recreation) $S$, and on trip characteristics, y. To allow the dependent variable to be dichotomous the use/non-use of agricultural land on the most recent day trip or overnight trip was modelled using logistic regression (logit model) (e.g., Hosmer and Lemeshow 2000). The probability that the individual will use agricultural land is

$$
\begin{aligned}
& \operatorname{prob}(\mathrm{SITE} \mathrm{TYPE}=1)= \\
& E(\operatorname{SITE} \mathrm{TYPE} \mid S, y)=\frac{1}{1+\exp (\beta S+\delta y)}
\end{aligned}
$$

where SITE TYPE receives values 0 and 1 .

In the second approach we estimate the demand function for trips to sites containing agricultural land. We apply the negative binomial model to obtain benefit estimates on the monetary value of recreation per trip. As we are interested in the whole entity of agricultural sites, we take the existence of agricultural land as a demand shifter. Contrary to traditional travel cost models focusing on a specific site, we model the demand for trips to a representative site (Creel and Loomis 1990, Zawacki et al. 2000), which is a combination of destinations defined by our sample rather than any single area. Knowing the number of trips to a destination area and the associated travel costs the expected trip demand, $Y$, can be modelled as a function of travel cost, $p$, and individual characteristics, $x$. As the dependent variable measured by the number of user days can receive only non-negative integer values, econometric techniques for analysing count data, such as the negative binomial regression model applied here, are appropriate for estimation (e.g., Cameron and Trivedi 1998). Because the sample does not include non-users, the distribution of use days is left-truncated. A zero truncated negative binomial regression model is of the form

$$
\begin{aligned}
& \operatorname{prob}(Y=y \mid Y>0)= \\
& {[\Gamma(y+1 / \alpha) / \Gamma(y+1) \Gamma(1 / \alpha)] .} \\
& (\alpha \lambda)^{y}(1+\alpha \lambda)^{-(y+1 / \alpha)}\left[1-F_{N B}(0)\right]^{-1}, \\
& y=1,2, \ldots
\end{aligned}
$$

where $\Gamma$ indicates the gamma function and $\alpha$ is the overdispersion parameter. The conditional mean of this model is $\mathrm{E}(\mathrm{Y} \mid x)=\lambda\left[1-\mathrm{F}_{\mathrm{NB}}(0)\right]^{-1}=\exp (\beta x)[1-$ $\left.\mathrm{F}_{\mathrm{NB}}(0)\right]^{-1}$ (Grogger and Carson 1991).

Integrating the demand function from beginning price $\mathrm{P}_{B}$ to choke price $\mathrm{P}_{C}$ we have an estimate for the consumer surplus of trips to a site

$$
C S=\int_{P_{B}}^{P_{C}} Y(p) d p=-\frac{Y}{\beta_{p}} .
$$

Accordingly, the average consumer surplus per predicted trip is

$$
\frac{C S}{Y}=-\frac{1}{\beta_{p}} .
$$

The annual benefits of the average site are calculated by estimating the average number of trips at the population level and multiplying it with estimated benefits per predicted trip (Creel and Loomis 1990). 
Vol. 15 (2006): 375-387.

In the following both of these approaches, the site type choice and aggregated travel cost approach, are used for both day trips and overnight trips.

\section{Data}

To analyse the suitability of agricultural sites for recreation and rural tourism the study used data from a population survey conducted as part of a national outdoor recreation demand and supply inventory that was carried out between August 1998 and May 2000 (Virtanen et al. 2001). The data were gathered in two phases: by telephone interview and a postal questionnaire. These surveys were targeted at Finns aged 15 to 74 . The total sample size was 12649 persons. Interview data were gathered from 10651 respondents (84\% of those sampled) and provided information on annual participation in recreational activities and on several socio-economic variables. The postal questionnaire was sent to those respondents who expressed their willingness during the telephone interview to complete it. Two thirds $(65 \%$ or 5535 persons) of those who received the questionnaire completed and returned it.

Information about day trips and overnight trips was obtained from responses to the postal questionnaire. A day trip was defined as a non-overnight trip that lasted over 15 minutes but less than 24 hours and the purpose of which was to participate in one or more outdoor recreational activities in nature. The average length of single day visits was 2.5 hours and the standard deviation was also 2.5 hours. Correspondingly, an overnight trip was defined as a trip that included spending at least one night at the location and was taken in order to participate in one or more outdoor recreational activities in nature. The average length of overnight trips was 5 days and the standard deviation 7 days. The questions focused on the respondent's most recent day and overnight trips. Respondents were asked about their last trip, one trip of each type, only if they had made at least one such trip during the pre- vious 12 months. In this manner, we received a sample of 4927 day trips and 2410 overnight trips.

The presence of agricultural land was used as the essential destination characteristic. The variable agricultural land was measured among 12 other factors characterising the natural environment of the destination site of the last visit or trip. The question was: "Did the destination area or site [of the last visits or trip] contain fields or meadows?" In the sample of day visits and overnight trips, agricultural land (field or meadows) was present in $41 \%$ of the sites of day trips (2018 sites) and on $34 \%$ of the sites of overnight trips (811 sites). Most of the destination sites were diverse landscapes and also included forests, water bodies or parks.

In addition to items dealing with destination site characteristics, a set of questions measured the characteristics of the most recent day trip and overnight trip according to the duration and length of the trip, activities, companions, mode of transportation and distance to the destination. The frequency data for travel cost models were gained from the questions related to the last trip. For overnight trips, the question concerning the number of visits focused on the last 5 years but was converted to an annual number of trips similar to day trips. Information about the expenditures incurred in connection with the visit or trip was elicited by asking the respondents to separate their personal travel, accommodation and activity expenditures (e.g. rental and participation fees, access fees, permit, equipment). These were summed to form the variable of total expenditures. Variables describing respondents' socio-economic background, monthly household income, gender, age and several other background variables were measured.

Data on the supply of agricultural land, forests and water bodies in each respondent's home municipality were obtained from agricultural and forest statistics. We also attempted to include variables describing the structure of the agricultural landscape in the analysis. Using the Patch Analyst of Arc View 3.1, which employs the FRAGSTATS 3.3 programme, 36 variables were estimated on the municipality level from the CORINE land cover data base. These variables were measures of the 
total area, patch density and size, edges, shape, diversity and interspersion, and core areas. To summarize this data we used principal component analysis to form dimensions on the municipality level to describe the landscape structure. We attempted to use these dimensions in the choice model of destination site type.

Within-municipality variation in the supply of various site types among the municipalities was based on an indicator variable, the respondents perceptions of whether their residence was located in a city or town centre, in a sparsely populated area or in an area characterised somewhere between these two categories.

\section{Results}

\section{Choice of site type}

In the following we first analyse the use and suitability of agricultural land for recreation. Using a logistic regression model on day trips ${ }^{1}$ and overnight trips we identify those factors that affected the probability that an individual respondent chose a destination that included agricultural land (Table $1)$. The explanatory variables in the models focused on the respondent's living environment as well as characteristics of a recreation visit, such as activities and expenses associated with the visit. Although the overall goodness of fit of the models was low, the models provide some insight into those variables of the data that significantly affected the probability of choosing a destination site with agricultural land. The models also allow us to evaluate the respondents' preferences for agricultural environment from the willingness to accept expenses related to visiting agricultural and other types of sites.

1 We also tried separate models for day trips shorter and longer than the median length. However, as there was no considerable difference between the two models, we decided to use only one model for all day trips.
From the model for day trips (Table 1) we can see that the respondent's living environment had an effect on the probability of visiting agricultural areas close to home for recreation purposes. As expected, as the amount of agricultural land relative to forest land increased, the probability of using an agricultural environment for recreation also increased. The geographical area also had a significant effect, such that in southern Finland the probability of using agricultural land on day trips was higher than in northern parts of the country. The use of agricultural land provided a substitute for some opportunities that were lacking or were in short supply in the primary residential environment. In the case of scarce water bodies in one's home municipality, the probability of using agricultural land was higher. Lakes and fields seemed to serve equally as scenically important open areas in an otherwise forest-dominated Finnish landscape. In the lake- and forest-rich provinces of eastern and central Finland the probability of using agricultural land for day trips was considerably lower than in south-west Finland, which has fewer lakes but more fields. The use of agricultural land for recreation was also less likely in the forested northern Finland. We were unable to include FRAGSTAT-based dimensions of the landscape structure in the model, as the first dimension correlated strongly with the relative amount of agricultural land. No other dimensions were significant in the model.

In our data, some of the 90 measured activities were associated with the use of agricultural land as a destination for day trips. Those uses that were significantly more likely to be associated with agricultural land included walking the dog, bicycling, visiting a vacation home or hunting. There are several reasons for this pattern. Bicycling tours cover large land areas and the probability that agricultural land is present is naturally higher. Visiting a vacation home brings people to rural areas. On day trips, participation in various activities in the immediate surrounding of a vacation home may also include agricultural environments. In the case of hunting, open areas are needed. In addition, the use of an agricultural site was more common when the activity was bird watching or horseback riding 
Vol. 15 (2006): 375-387.

$\left(\chi^{2}\right.$-test, $\left.\mathrm{P}<0.05\right)$. Due to the small number of such reports, however, these variables were not significant in the logistic model.

Of the other trip characteristics, the existence of accompanying persons was negatively associated with the presence of agricultural land on the site. Agricultural land close to home was more likely to be visited alone than other types of areas. In $41.3 \%$ of cases, respondents were alone on agricultural land. On other types of areas, $37.5 \%$ of day trips were made alone. This indicates that visiting agricultural land is typically not a special event, but rather an everyday activity.

The coefficient for visit expenses means that an increase in travel expenses, with all else unchanged, reduced the probability of choosing a destination with agricultural land for day trips. Recalling that we are considering the choice between the two site types given that a trip is taken, and not the decision whether to take a trip or the number of trips, trip expenses would not have an effect if both site types were equally valued as destinations. Thus, the result suggests a lower preference for agricultural areas in comparison to other land use categories, such as forests. Agricultural land does not seem to be a special attraction that is worth travelling long distances to reach. However, the evidence that agricultural areas are inferior destinations should not be overstated. Besides conscious choice based on scenic preferences and relative site amenities, the coefficient may in part reflect the simple facts that agricultural land is in abundant supply near residential areas (hence, much used for day visits just for easy access), and that the related visit expenses are low due to proximity. However, a variable describing residence in city centre or in sparsely populated areas was included to capture the effect of within-municipality supply and to reduce the possibility of two-way causation.

The second model in Table 1 shows factors affecting the choice of an agricultural environment as the destination of overnight trips. The probability of travelling to areas with agricultural land was highest among respondents living in southern Finland, where the relative proportion of agricultural areas is highest. However, the model also shows that a high ratio of agricultural to forest land in the living environment decreased the probability that a respondent would travel to areas with agricultural land. Thus, it seems that on their overnight trips respondents sought greater variety with respect to the large share of agricultural land in their living environment.

Some characteristics of overnight trips were significantly associated with the presence of agricultural land at the destination site. In the case of hunting trips and trips taken to a vacation home, the probability of using agricultural land was higher than in the case of other activities. In addition, trips associated with activities such as walking and horseback riding were significantly more often taken to an agricultural environment than to other types of environment $\left(\chi^{2}\right.$-test, $\left.\mathrm{P}<0.05\right)$, although these activities were not significant in the model. Similarly to the case of day trips, the probability of choosing a site with agricultural land decreased significantly at the $10 \%$ level with an increase in visit expenses.

\section{Demand for and benefits of visiting agricultural sites}

Travel cost models of recreational demand were estimated separately for day trips and overnight trips with the truncated negative binomial regression model (Table 2). As the significant alpha coefficient reveals, the negative binomial model is suitable for these overdispersed data. As the demand theory assumes, an increase in travel cost decreases the visitation in both models. In the case of overnight trips the income variable is also significant, implying a lower number of trips for lower income groups. However, in the day trip model the effect of income was not significant. The presence of agricultural land at the destination increased the number of trips in both models. This would imply that with visit expenses held constant, agricultural land would be visited more often than other types of land. To analyse the effect of the agricultural environment in more detail we formed an interaction variable of travel cost and agricultural land. A 
Pouta, E. \& Ovaskainen, V. Assessing the recreational demand for agricultural land in Finland

Table 1. Logistic regression models for the choice of a destination with agricultural land.

\begin{tabular}{|c|c|c|c|c|}
\hline & \multicolumn{2}{|c|}{ Day trips } & \multicolumn{2}{|c|}{ Overnight trips } \\
\hline & Co-efficient & P-value & Co-efficient & P-value \\
\hline \multicolumn{5}{|l|}{ Characteristics of living environment (home municipality) } \\
\hline Agricultural land/ forest land & 0.004 & 0.066 & -0.008 & 0.017 \\
\hline Relative share of water bodies & -1.730 & 0.000 & & \\
\hline Southern Finland (reference level) & & 0.001 & & 0.000 \\
\hline Eastern Finland & 0.008 & 0.946 & -0.525 & 0.001 \\
\hline Northern or Western Finland & -0.316 & 0.000 & -0.479 & 0.000 \\
\hline Residence in a city or town centre & -0.403 & 0.000 & & \\
\hline Residence in a sparsely populated area & 0.450 & 0.000 & & \\
\hline \multicolumn{5}{|l|}{ Characteristics of trip } \\
\hline Activity: walking the dog & 0.514 & 0.000 & & \\
\hline Activity: bicycling & 0.262 & 0.030 & & \\
\hline Activity: visiting a vacation home & 0.534 & 0.001 & 0.747 & 0.000 \\
\hline Activity: hunting & 0.750 & 0.001 & 0.842 & 0.004 \\
\hline Taken alone & 0.162 & 0.019 & & \\
\hline Visit expenses & -0.011 & 0.003 & -0.001 & 0.106 \\
\hline Constant & -0.348 & 0.000 & -0.370 & 0.002 \\
\hline $\mathrm{N}$ & 4111 & & 1851 & \\
\hline Proportion of agricultural land users (\%) & 42 & & 34.8 & \\
\hline Proportion of correctly classified trips (\%) cut-off point 0.50 & 60.3 & & 66.0 & \\
\hline Log likelihood for model & -2709 & & -1162 & \\
\hline Log likelihood for constant & -2796 & & -1195 & \\
\hline Likelihood ratio test $\left(\chi^{2}\right)$ & 176 & & 66.60 & \\
\hline df & 12 & & 6 & \\
\hline P-value & $<0.0001$ & & 0.000 & \\
\hline Pseudo R² & 0.031 & & 0.027 & \\
\hline Nagelkerke $\mathrm{R}^{2}$ & 0.056 & & 0.049 & \\
\hline
\end{tabular}

negative and significant coefficient for this variable would mean that the respondents are more sensitive to travel expenses in the case of destinations with agricultural land and less willing to travel long distances to such destinations. This was the case in the overnight trip model, while in the model for day trips the coefficient for the interaction variable did not differ significantly from zero. Based on this, agricultural land seems to be an inferior recreational environment for rural tourists while indifferent in the case of day trips.

The travel cost models were used to estimate the per-trip and annual benefits of visits (Table 3). For day trips, the presence of agricultural land ac- tually made no significant difference to the estimated benefits per trip. For overnight trips, however, the estimated per-trip consumer surplus for sites without agricultural land was about 10\% higher than for sites with agricultural land. The estimated negative binomial models were used to compute the expected numbers of day trips and overnight trips for the population considered. The expected numbers of day and overnight trips were, respectively, 45 and 1.3 per person for sites with agricultural land and 29 and 0.8 per person for other site types. Using these estimates the annual consumer surplus estimates per person (Table 3) were calculated. Because of the higher trip fre- 
Vol. 15 (2006): 375-387.

Table 2. Recreational demand for agricultural sites, truncated negative binomial models.

\begin{tabular}{|c|c|c|c|c|}
\hline & \multicolumn{2}{|c|}{ Day trips } & \multicolumn{2}{|c|}{ Overnight trips } \\
\hline & Co-efficient & $\mathrm{P}$-value & Co-efficient & P-value \\
\hline Visit expenses, $€$ & -0.0511 & 0.0000 & -0.0175 & 0.0000 \\
\hline Agricultural land & 0.3730 & 0.0000 & 0.4007 & 0.0001 \\
\hline Agricultural land $\mathrm{x}$ visit expenses & 0.0057 & 0.1866 & -0.0021 & 0.0001 \\
\hline Income & -0.0045 & 0.5948 & 0.0689 & 0.0000 \\
\hline Constant & 3.5753 & 0.0000 & 1.3426 & 0.0000 \\
\hline Alpha & 3.6718 & 0.0000 & 2.9649 & 0.0000 \\
\hline $\mathrm{N}$ & 3652 & & 1574 & \\
\hline Log likelihood for model & -16641 & & -2672 & \\
\hline Log likelihood for constant & -175722 & & -5918 & \\
\hline$\chi^{2}$ & 318162 & & 6491 & \\
\hline df & 1 & & 1 & \\
\hline P-value & 0.000 & & 0.000 & \\
\hline Pseudo $\mathrm{R}^{2}$ & 0.78 & & 0.55 & \\
\hline
\end{tabular}

Table 3. Consumer surplus per predicted trip and annually.

\begin{tabular}{|c|c|c|c|c|}
\hline \multirow[b]{2}{*}{ Consumer surplus } & \multicolumn{2}{|c|}{ Day trips } & \multicolumn{2}{|c|}{ Overnight trips } \\
\hline & $\begin{array}{l}\text { Agricultural land } \\
\text { at destination }\end{array}$ & $\begin{array}{c}\text { No agricultural land } \\
\text { at destination }\end{array}$ & $\begin{array}{l}\text { Agricultural land } \\
\text { at destination }\end{array}$ & $\begin{array}{c}\text { No agricultural land } \\
\text { at destination }\end{array}$ \\
\hline$€$ per trip & 22 & 20 & 51 & 57 \\
\hline$€$ per year & 999 & 582 & 68 & 45 \\
\hline
\end{tabular}

quency to agricultural destinations the annual benefits are considerably higher for sites with agricultural land than for other site types.

\section{Discussion and conclusion}

Based on the total number of people participating in recreation generally and the median number of day trips and overnight trips (Pouta and Sievänen 2001), Finns annually make about 180 million day trips and spend 4.6 million overnight trip days in an agricultural environment. Because agricultural land plays a particularly important role as a recreational environment for day visits close to home, the importance of agricultural land is especially great around towns and cities in suburban and rural areas (compare Hall et al. 2004). However, the suitability of agricultural land as a recreational environment cannot be evaluated only on the basis of the number occasions on which a particular land type was used.

Based on the choice models we can conclude that agricultural lands provide a substitute for open landscapes in aquatic environments and forest areas when time or money to visit these sites are limited. Goossen and Langers (2000) showed that a mixed area comprising various land use types and biotopes is preferable for recreational activities. In our study we used the proportions of various land use types to characterise the environment. However, variables of this sort do not describe the structure of the landscapes, such as the special 
configuration of fields and forests. Neither was it possible using the data of this study to define the nature or extent of that part of the visit that relates to agricultural land. Analysis of the optimal mixture of land use forms for recreational use would be an interesting topic for future research.

In our study the per-trip consumer surplus estimates were roughly twice as high as the estimates from previous site-specific travel cost studies in Finland (Ovaskainen et al. 2001a, b, from 1990 and 1996 data, respectively). However, our estimates were less than one tenth of those reported by Fleischer and Tsur (2000). In contrast to our case, they found agriculture to increase the per-trip benefit estimates from the travel cost model. Results from hedonic price studies are not directly comparable, as their focus was on the effect of agriculture on accommodation prices (Le Goffe and Delache 1997, Vanslembrouck et al. 2005). In these studies, intensive livestock farming reduced accommodation prices but less intensive agriculture in the form of permanent grasslands had a positive effect on tourism prices.

In the Finnish case it would also be interesting to focus on the recreational quality of agricultural sites. As the actual recreational use of agricultural land is only possible using field tracks, paths by ditches and on buffer strips, it would be interesting to evaluate the extent to which present agricultural practices provide these characteristics. We attempted to include the variables describing the landscape structure in our analysis, but the problem was the high correlation of these variables with the relative amount of agricultural land. However, from the literature we know that the modernisation of agriculture has decreased traditional pasture habitats, edge density, and the area of ditch margins. We also know that it has made the landscape more homogenous (Hietala-Koivu 2002). These changes all reduce the opportunities for recreation on agricultural land. However, it might be possible that increased use of buffer strips and the restoration of pasture habitats related to the environmental support of agriculture might compensate for some of these changes.

The general pattern of overnight trips to rural areas in Finland reveals that approximately one third of all tourist trips are to northern Finland (Pouta et al. 2004), while in southern Finland rural tourism is less developed. Land ownership patterns in southern Finland, which are characterised by a large number of small, private forest parcels, may be one of the reasons why the development of large-scale nature-based recreational opportunities has remained limited. Overnight trips associated with a vacation home are particularly characteristic in southern Finland. A family vacation home is the destination of $30 \%$ of overnight nature trips made by Finns. Judging from these figures, only about $30 \%$ of nature trips in southern Finland are taken to areas other than a vacation home. This $30 \%$ share defines the potential for tourism from a rural development perspective. An interesting topic would be an analysis of site choice and the effect of agricultural land for this $30 \%$ share by using site aggregation based on geographic regions.

While prior research has shown the scenic importance of agricultural environments, we have attempted to determine whether these landscapes are being fully utilized and whether they are suitable for recreation and tourism. As the estimated benefits for overnight trips are lower in the case of agricultural destinations, the study does not support the idea that agricultural environments in their present state could be an attraction that succeeds in drawing tourists to remote rural areas. As agriculture is strongly subsidised, partly for its public good provision and multifunctionality, it would also be important to focus on increasing the production of these public goods. The scenic properties of agricultural land could be fully utilised by evaluating how the management of these areas could promote recreation opportunities. In this way, agricultural landscapes could attract visitors and thereby produce income in rural areas.

\section{References}

Agricultural statistics in Finland 2005. Matilda information service. Cited 10 Aug 2005. Available on the Internet: http://www.matilda.mmm.fi.

Arriaza, M., Cañas-Ortega, J.F., Cañas-Madueño, J.A. \& Ruiz-Availes, P. 2004. Assessing the visual quality of 
Vol. 15 (2006): 375-387.

rural landscapes. Landscape and Urban Planning 69: 115-125.

Bonnieux, F., Rainelli, P. \& Vermersch, D. 1998. Estimating the supply of environmental benefits by agriculture: a French case study. Environmental and Resource Economics 11: 135-153.

Cameron, A.C. \& Trivedi, P.K. 1998. Regression analysis of count data. Econometric Society Monographs No: 30. Cambridge University Press, New York. 432 p.

Creel, M.D. \& Loomis, J.B. 1990. Theoretical and empirical advantages of truncated count data estimators for analysis of deer hunting in California. American Journal of Agricultural Economics 72: 434-441.

Dillman, B.L. \& Bergstrom, J.C. 1991. Measuring environmental amenity benefits of agricultural land. In: Hanley, N. (ed.) Farming and the countryside, an economic analysis of external costs and benefits. CAB International, Wallingford. p. 250-2171.

Dobbs, T. \& Pretty J. 2004. Agri-environmental stewardship schemes and "multifunctionality" Review of Agricultural Economics 26: 220-237.

Englin, J., Boxall, P.C., Chakraborty, K. \& Watson, D.O. 1996. Valuing the impacts of forest-fires on backcountry forest recreation. Forest Science 42: 450-455.

Finnish Environment Administration 2005. Perinnemaisemat ja -biotoopit. Accessed 10 Aug 2005. Available on the Internet: http://www.ymparisto.fi.

Fleischer, A. \& Felsenstein, D. 2000. Support for rural tourism - Does it make a difference? Annals of Tourism Research 27: 1007-1024.

Fleischer, A. \& Tchetchik, A. 2005. Does rural tourism benefit from agriculture? Tourism Management 26, 4: 493501.

Fleischer, A. \& Tsur, Y. 2000. Measuring the recreational value of agricultural landscape. European Review of Agricultural Economics 27: 385-398.

Fleischer, A. \& Tsur, Y. 2003. Measuring the recreational value of open space. Journal of Agricultural Economics 54: 269-283.

Garrod, G. \& Whitby, M.C. 2005. Strategic countryside management. Elsevier. 348 p.

Goossen, M. \& Langers, F. 2000. Assessing quality of rural areas in the Netherlands: finding the most important indicators for recreation. Landscape and Urban Planning 46: 241-251.

Grogger, J.T. \& Carson, R.T. 1991. Models for truncated counts. Journal of Applied Econometrics 6: 225-238.

Hackl, F. \& Pruckner, G. 1997. Towards more efficient compensation programmes for tourists' benefits from agriculture in Europe. Environmental and Resource Economics 10: 189-205.

Hall, C., McVittie, A. \& Moran, D. 2004. What does the public want from agriculture and the countryside? A review of evidence and methods. Journal of Rural Studies 20: 211-225.

Hietala-Koivu, R. 2002. Landscape and modernizing agriculture: a case study of three areas in Finland in 19541998. Agriculture, Ecosystems and Environment 91: 273-281.

Hosmer, D.W. \& Lemeshow, S. 2000. Applied logistic regression. 2nd ed. John Wiley and Sons, New York. $392 \mathrm{p}$.
Karjalainen, E. \& Komulainen, M. 1998. Field afforestation preferences: A case study in northeastern Finland. Landscape and Urban Planning 43: 79-90.

OECD 2001. Multifunctionality, towards an analytical framework. OECD, Paris. 157 p.

Le Goffe, P. 2000. Hedonic pricing of agriculture and forestry externalities. Journal Environmental and Resource Economics 15: 397-401.

Le Goffe, P. \& Delache, X. 1997. Impacts de l'agriculture sur le tourisme: une application des prix hedonistes. Economie Rurale 239: 3-10.

Ovaskainen, V., Horne, P. \& Mikkola, J. 2001a. Retkeilyalueiden ja kansallispuistojen virkistyskäytön arvo. In: Kangas, J. \& Kokko, A. (eds.). Metsän eri käyttömuotojen arvottaminen ja yhteensovittaminen. Metsäntutkimuslaitoksen tiedonantoja 800. p. 215-229. (The recreation use value of national parks and hiking areas based on travel cost and contingent valuation methods, in Finnish)

Ovaskainen, V., Mikkola, J. \& Pouta, E. 2001b. Estimating recreation demand with on-site data. An application of truncated vs. truncated, endogenously stratified count data models. Journal of Forest Economics 7: 125-144.

Parsons, G.R. \& Kealy, M.J. 1992. Randomly drawn opportunity sets in a random utility model of lake recreation. Land Economics 68: 93-106.

Peterson, J., Boisvert, R.N. \& de Gorter, H. 2002. Environmental policies for a multifunctional agriculture in open economies. European Review of Agricultural Economics 29: 423-443.

Pouta, E., Neuvonen, M. \& Sievänen, T. 2006. Determinants of nature trip expenditures in Southern Finland - implications for nature tourism development. Scandinavian Journal of Hospitality and Tourism 6: 118-135.

Pouta, E. \& Sievänen, T. 2001. Luonnon virkistyskäytön kysyntätutkimuksen tulokset - kuinka suomalaiset ulkoilevat. (Results of an outdoor recreation demand study - how Finns participate in outdoor recreation). In: Sievänen, T. (ed.). Luonnon virkistyskäyttö 2000. Luonnon virkistyskäytön valtakunnallinen inventointi LVVItutkimus, 1997-2000 Loppuraportti. Metsäntutkimuslaitoksen tiedonantoja 802. p. 32-68.

Raffaelli, R., Notaro, S., Goio, I. \& Gios, G. 2004. Multifunctional agriculture, policies and markets: understanding the critical linkage. In: 90th EAAE Seminar, Multifunctional agriculture, policies and markets: understanding the critical linkage. Proceedings of 90th EAAE Seminar, Rennes, 28-29 October 2004. p. 91-108.

Randall, A. 2002.Valuing the outputs of multifunctional agriculture. European Review of Agricultural Economics 29: 289-307.

Ready, R.C., Berger, M.C. \& Blomquist, G.C. 1997. Measuring amenity benefits from farmland: hedonic pricing vs. contingent valuation. Growth and Change 28: 438458.

Rosenberger, R.S. \& Walsh, R.G. 1997. Nonmarket value of Western valley ranchland using contingent valuation. Journal of Agricultural and Resource Economics 22: 296-309.

Skuras, D., Petrou, A. \& Clark, G. 2006. Demand for rural tourism: the effects of quality and information. Agricultural Economics 35: 183-192. 


\section{AGRICULTURAL AND FOOD SCIENCE}

Pouta, E. \& Ovaskainen, V. Assessing the recreational demand for agricultural land in Finland

Slee, B., Farr, H. \& Snowdon, P. 1997. The economic impact of alternative types of rural tourism. Journal of Agricultural Economics 48: 179-192.

Tahvanainen, L., Ihalainen, M., Hietala Koivu, R., Kolehmainen, O., Tyrväinen, L., Nousiainen, I. \& Helenius, J. 2002. Measures of the EU Agri-Environmental Protection Scheme (GAEPS) and their impacts on the visual acceptability of Finnish agricultural landscapes. Journal of Environmental Management 66: 213-227.

Tyrväinen, L. \& Tahvanainen, L. 2000. Impacts of afforestation on the scenic value of rural countryside. In: Weber, N. (ed.). NEWFOR - New forests for Europe: afforestation at the turn of the century. European Forest Institute (EFI) Proceedings 35. Joensuu. p. 141-150.

Van Huylenbroeck, G., Vanslembrouck, I., Calus, M. \& Van de Velde, L. 2006. Synergies between farming and rural tourism: evidence from Flanders. Eurochoices 5: 1422.

Vanslembrouck, I. \& Van Huylenbroeck, G. 2005. Landscape amenities: economic assessment of agricultural landscapes. Springer, Landscape Series, Volume 2. $202 \mathrm{p}$.

Vanslembrouck, I., Van Huylenbroeck, G. \& Van Meensel, J. 2005. Impact of rural tourism: a hedonic pricing approach. Journal of Agricultural Economics 56: 17-30.
Virtanen, V., Pouta, E., Sievänen, T. \& Laaksonen, S. 2001. Luonnon virkistyskäytön kysyntätutkimuksen aineistot ja menetelmät. (The data and the methods in outdoor recreation demand study). In: Sievänen, T. (ed.). Luonnon virkistyskäyttö 2000. Luonnon virkistyskäytön valtakunnallinen inventointi LVVI-tutkimus, 1997-2000 Loppuraportti. Metsäntutkimuslaitoksen tiedonantoja 802. p. 19-27.

Wytrzens, H.K. \& Mayer, C. 1999. Multiple use of alpine grassland in Austria and the implications for agricultural policy. Bodenkultur 50: 251-261.

Ympäristöministeriö 2002. Ohjelma luonnon virkistyskäytön ja luontomatkailun kehittämiseksi. Suomen ympäristö 535. Ympäristöministeriö, Helsinki. 48 p. (Programme for developing recreation in the wild and nature tourism by the Ministry of the Environment, in Finnish)

Yrjölä, T. \& Kola, J. 2004. Consumer preferences regarding multifunctional agriculture. International Food and Agribusiness Management Review 7: 78-90.

Zawacki, W.T, Marsinko, A. \& Bowker, J.M. 2000. A travel cost analysis of nonconsumptive wildlife-associated recreation in the United States. Forest-Science 46: 496-506. 


\title{
SELOSTUS
}

\section{Maatalousympäristön virkistyskysynnän arviointi}

\author{
Eija Pouta ja Ville Ovaskainen \\ MTT Taloustutkimus ja Metsäntutkimuslaitos
}

Hoidettuja peltoja arvostetaan maisemassa, mutta maatalousmaata ei ole mielletty keskeiseksi osaksi ihmisten virkistysympäristöä. Kuitenkin noin 40 \% suomalaisten lähiulkoilukerroista tapahtuu maatalousympäristössä. Tämä tarkoittaa noin 180 miljoonaa ulkoilukertaa ympäristössä, jossa on maatalousmaata. Maaseutumatkoista puolestaan noin kolmasosa tehdään alueille, joilla harjoitetaan metsätalouden ohella myös maataloutta. Tämä tarkoittaa noin 4,6 miljoonaa matkapäivää vuosittain.

Tutkimuksen tavoitteena on selventää maatalousympäristön merkitystä luonnon virkistyskäytölle ja maaseutumatkailulle. Tutkimuksessa selvitetään tekijöitä, jotka vaikuttavat kohdealueen valintaan maatalousympäristön ja muunlaisen kohteen välillä. Matkakustannusmenetelmää soveltaen mallinnetaan ulkoilukertojen kysyntä ja arvotetaan erilaisille kohdealueille suuntautuvia käyntikertoja.

Tutkimuksessa käytettiin luonnon virkistyskäytön valtakunnallisen inventoinnin aineistoa. Aineiston pohjalta rakennettiin tilastollisia malleja ulkoilukohteen tyypin valinnalle (maatalousympäristö/muu ympäristö) ja ulkoilukertojen kysynnälle erityyppisillä kohdealueilla. Mallit kuvasivat päiväretkiä ja yöpymisen sisältäviä maaseutumatkoja. Kohdealueen valintaa tarkasteltiin logistisella regressiomallilla, ja ulkoilukertojen kysyntää negatiiviseen binomijakaumaan perustuvilla regressiomalleilla.

Maatalousympäristöllä oli merkitystä ulkoilukohteena erityisesti niillä paikkakunnilla, joilla maatalousmaan suhteellinen osuus oli suuri. Myös pieni vesialueiden osuus ohjasi ihmiset valitsemaan maatalousympäristön ulkoilukohteeksi. Maatalousympäristössä ulkoil- tiin näin ollen erityisesti Etelä-Suomessa. Maatalousympäristöön kohdistuvat ulkoilukerrat poikkesivat muista ulkoilukerroista jonkin verran. Maatalousympäristössä ulkoiltiin muita kohteita useammin yksin, ja siihen oltiin valmiita käyttämään vähemmän rahaa kuin muissa kohteissa ulkoiluun. Maatalousympäristöön lähdettiin erityisesti silloin, kun harrastuksena oli metsästys, koiran ulkoiluttaminen tai pyöräily. Maatalousympäristössä virkistäydyttiin myös kesämökkeillen.

Ulkoilukerran tuottamia hyötyjä arvioitiin rahassa ulkoilukertojen määrän ja kustannusten perusteella estimoidun ulkoilukertojen kysyntäfunktion avulla. Ulkoilukerrasta tai -päivästä arvioitiin saadun 20 eurosta 60 euron hyöty. Kodin lähialueilla ulkoiltaessa ulkoilun hyödyt olivat yhtä suuret niin maatalous- kuin esimerkiksi metsäympäristössäkin. Tulokset osoittivat kuitenkin, että yöpymisen sisältävillä matkoilla matkustamisesta sellaiseen kohteeseen, jossa ei ollut maatalousympäristöä, oltiin valmiita maksamaan enemmän kuin maatalousympäristökohteesta. Näin ollen maatalousympäristöä nykyisellään arvostettiin muita ympäristöjä vähemmän.

Koska matkailusta toivotaan varteenotettavaa elinkeinoa maaseudulle, olisikin tärkeää miettiä sitä, kuinka maatalousympäristöä voitaisiin kehittää vetovoimatekijänä. Maisema-arvoja ja ulkoilua tukevien viljelykäytäntöjen myötä jokamiehenoikeudella tapahtuvan ulkoilun ja maaseutumatkailun tuottamat hyödyt kasvaisivat. Tällä olisi merkitystä erityisesti Etelä-Suomessa, missä lähivirkistäydytään paljon maatalousympäristössä ja maaseutumatkailu nähdään keskeisenä maaseudun elinvoimaisuutta ylläpitävänä elinkeinona. 